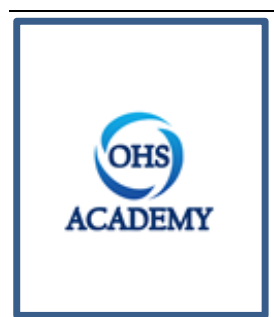

OHS ACADEMY

İs Să̆lı̆̆ı ve Güvenliği Akademi Dergisi

Açı Erişim

Journal of Occupational Health and Safety Academy

Open Access

\title{
Yükseköğretim Kurumlarında İş Sağlığı ve Güvenliğine Yaklaşım, İstanbul Örneği
}

\author{
Ahmet ÇABUK ${ }^{1 *}$, Dilan ONĞULU ${ }^{2}$ \\ ${ }^{1}$ Mülkiyet Koruma ve Güvenlik Bölümü, Meslek Yüksekokulu, Beykoz Üniversitesi, İstanbul, Türkiye \\ ${ }^{2}$ Meslek Yüksekokulu, İstanbul Medipol Üniversitesi, İstanbul, Türkiye
}

Makale Tarihçesi

Gönderim: $\quad 07.04 .2021$

Kabul: $\quad 20.04 .2021$

Yayım: $\quad 30.04 .2021$

Araștırma Makalesi
Öz- Yükseköğretim kurumları lisansüstü, lisans ve ön lisans seviyesinde eğitim ve öğretimin gerçekleştirildiği kurumlar olup bünyesinde derslik, atölye, laboratuvar, sağlık, kültür ve spor faaliyetlerinin gerçekleștirildiği alanlar, mutfak, depo, büro gibi birçok kısımları içermektedir. Bu alanlarda kullanılan makine, teçhizat, aletin yanı sıra alanların fiziksel, kimyasal, psikolojik, ergonomik koşulları bulunmaktadır. Üniversite sınırları içerisinde bulunan tüm paydaşlar (Öğrenci, öğretim elemanı, idari personel, ziyaretçi, tedarikçi) tüm etkenlerden etkilenmektedir. İstanbul ili içerisinde faaliyette bulunan üniversitelerde eğitim ve öğretimde görev alan öğretim elemanlarına yönelik yapılan çalışma ile yükseköğretim kurumlarında iş sağlığı ve güvenliği eğitimlerinin verilme durumu, ögretim elemanlarının ramak kala olay ve iş kazasına maruz kalma durumu, ramak kala olay ve iş kazasının bildirilmesi ve yetkili birimlerce ramak kala olaya ve iş kazasına neden olan etkeni ortadan kaldırmaya yönelik çalışma yapma durumu belirlenmeye çalışılmıştır. Yükseköğretim kurumlarında iş sağlı̆̆ı ve güvenliği konusunda çalışmaların etkin olarak yerine getirilmesi yükseköğretim kurumlarının tüm paydaşlar için sağlıklı ve güvenli hale getirilmesine olanak sağlayacaktır. Öğretim elemanlarının iş sağlığı ve güvenliği konusundaki risk algısının artması, iş sağlığı ve güvenliği çalışmalarına etkin olarak katılmasıyla sahip oldukları deneyimi direkt veya dolaylı olarak öğrencilere aktarmasıyla mezun olan öğrenciler iş yaşamlarında iş sağlığı ve güvenliğine dikkat edeceklerdir.

\section{Approach to Occupational Health and Safety in Higher Education Institutions, Istanbul Example}

\author{
Ahmet ÇABUK $^{1 *}$, Dilan ONĞULU ${ }^{2}$ \\ ${ }^{1}$ Property Protection and Security Department, Vocational School, University of Beykoz, Istanbul, Turkey \\ ${ }^{2}$ Vocational School, Medipol Istanbul University, Istanbul, Turkey
}

\section{Article History \\ Received: $\quad 07.04 .2021$ \\ Accepted: $\quad 20.04 .2021$ \\ Published: $\quad 30.04 .2021$}

Research Article

\begin{abstract}
Higher education institutions are institutions where education and training at graduate, undergraduate and associate degree levels are carried out and include many parts such as classrooms, workshops, laboratories, areas where health, culture, sports activities are carried out, kitchen, warehouse and office. In addition to machinery, equipment and tools used in these areas, the areas have physical, chemical, psychological and ergonomic conditions. All stakeholders within the boundaries of the university (student, academic staff, administrative staff, visitors, suppliers) are affected by all factors.The study conducted for academic staff working in education and training in universities operating in the province of Istanbul, the state of providing occupational health and safety training in higher education institutions, the situation of academic staff to be exposed to near-miss incidents and occupational acci-dents, notification of near-miss incidents and occupational accidents and close by the authorized units It has been tried to determine the situation of working to eliminate the factor that causes the incident and work accident. Effective performance of work on occupational health and safety in higher education institutions will enable higher education institutions to be made healthy and safe for all stakeholders. Students who gradu-ate will pay attention to occupational health and safety in their work lives by transferring their experience directly or indirectly to the students by increasing the risk perception of the academic staff about occupa-tional health and safety and their active participation in occupational health and safety studies.
\end{abstract}

Keywords - Higher education institution, occupational health and safety, risk communication, risk perception,

1 ahmetcabuk@beykoz.edu.tr

2 dilannongulu@gmail.com

Orcid id: 0000-0003-2593-9586

* Sorumlu Yazar: ahmetcabuk@ @eykoz.edu.tr, Beykoz Üniversitesi Kavacık/ İSTANBUL 


\section{Giriș}

Yaşam kalitesi, insanın içinde bulunduğu toplumda kendi yaşamını algılayış biçimidir ve küresel bazda toplumların ulaşmak ve sürdürülebilirliğini sağlamak istediği bir hedef olup bunun sebebi olarak Maslow'un "İhtiyaçlar Hiyearşisi” gösterilebilmektedir. Bu hiyerarşide insanın ihtiyaç öncelikleri sırasıyla; fiziksel ihtiyaçlar, güvenlik ihtiyacı, sosyal ihtiyaçlar, saygı görme ihtiyacı, kendini gerçekleştirme ihtiyacı şeklindedir. Yaşam kalitesinin söz konusu olabilmesi için değinilen tüm gereksinimlerin var olması ve üst düzeyde tutulmaya çalışılması önemlidir. Bireyin yaşı, medeni durumu, cinsiyeti, sağlık ve eğitim bilgileri, geliri, çalışma ortamındaki iş yaşamı, aldığı sosyal destek, yaşadığ konut, boş zaman aktiviteleri yaşam kalitesi göstergeleridir. İnsan yaşamının büyük bir kısmını iş yaşamında geçirmekte olduğundan, çalışma ortamındaki kötü çalışma şartları, yetersiz çalışma ortamı yaşam kalitesini doğrudan etkilemektedir. İş yerindeki çalışanların ilgisini çeken, sorumluluk alabileceği bir işte çalıştıklarında ve gelir, hizmet yılı, pozisyonları arttıkça iş yaşamı kalitesi dolayısıyla da yaşam kalitesinin arttı̆̆ı gözlemlenmiştir. Çalışma yaşamındaki sosyal ve fiziksel olanaklar iyileştirildikçe insanın iş tatmini artmaktadır (Aydıner, 2016). Çalışma ve sosyal yaşam alanları insanların çevreleriyle sürekli etkileşim halinde oldukları alanlardır. Bu iki ortamın maddi ve manevi özellikleri insanların yaşam kalitelerinin belirlenmesinde direkt olarak etkilidir. Çalışma ortamı veya sosyal yaşam alanından herhangi birisinde veya her ikisinde birden meydana gelebilecek olumsuz durumlar bireyin fiziksel, ruhsal ve sosyal açıdan olumsuz etkilenmesine ve dolayısıyla yaşam kalitesinin bozulmasına neden olmaktadır. Yaşam kalitesinin bileşeni olan çalışma hayatının kalitesinin arttırılması, işyeri ekosisteminin korunması, geliştirilmesi ve sürdürülebilirliğinde işyerlerinde gerçekleştirilen iş sağlığı ve güvenliği çalışmaları önemlidir. İş sağlığ ve güvenliği, iş yeri ekosistemini oluşturan tüm canlı ve cansız varlıkların sağlığını ve güvenliğini korumak ve devamlılıklarını sağlamak için yapılan ve geliştirilen çalışmaların bütünü olarak tanımlanmaktadır (Çabuk, 2020).

Çalışma hayatından yeterli düzeyde verim alabilmenin ve insana yakışır iş olanaklarının sağlanması için en temel ihtiyaçlardan biri sağlıklı ve güvenli çalışma ortamlarını oluşturmaktır. Çalışma koşulları, makine, iş süreci, kullanılan hammadde, kimyasal madde, alet ve ekipman, yeni işgücü zaman içinde değişebilmektedir. Konu iş yaşamı olduğunda her değişim yeni tehlikeleri ve riskleri meydana getirmektedir. İş sağlığı ve güvenliği hizmetleri yerine getirilmediğinde iş yerlerinde mevcut olan veya dişarıdan gelebilecek tehlikeler riske dönüşerek iş kazasına, meslek hastalığına ve ramak kala olayların meydana gelmesine neden olabilmektedir. Geçirilen iş kazası tutulunan meslek hastalığı ve meydana gelen ramak kala olayların nedenlerine arasında aydınlatma, termal konfor, gürültü, titreşim vb. fiziksel unsurlara; yaş, cinsiyet, eğitim, medeni durum vb. kişisel unsurlara; algılama farklılığı, iş tatmini, stres, öfke, zekâ seviyesi vb. ise fizyolojik, psikolojik ve sosyal unsurlar bulunmaktadır (Ünsar, 2004).

Uluslararası çalışma örgütü (ILO) tarafından yapılan açıklamaya göre her sene 2,78 milyon çalışan iş ile ilgili kaza ve hastalıklardan dolayı yaşamını kaybetmekte, 374 milyon insan ölümcül olmayan kazalardan etkilenmektedir (ILO, 2019). Sosyal Güvenlik Kurumu tarafından yayımlanan istatistiğe göre 2019 yılında Türkiye'de tüm ekonomik sınıflarda 422.463 çalışan iş kazası geçirmiş ve 1.088 kişi ise meslek hastalığına tutulmuştur. İş kazası sonucu ise 1.147 çalışan hayatını kaybetmiştir. Eğitim, bilimsel araştırma ve geliştirme, diğer mesleki, bilimsel ve teknik faaliyetlerin yapıldığı işyerlerinde 8.311 kişi iş kazası geçirmiş ve 1 çalışan meslek hastalığına tutulmuştur. İş kazası sonucu 6 çalışan yaşamını kaybetmiştir (SGK, 2019).

İş kazaları ve meslek hastalıkları sonucunda çalışanlar başta çalışan olmak üzere işyerinde bulunanlar, kazanın meydana geldiği işyeri ve işyeri çevresinde bulunan insan, insan dışındaki canlı ve cansız varlıklar zarar görmektedir. Meydana gelen zararlar insanlarda ölüm, yaralanma, iş gücü kaybı ve maddi gelirde kayıp ile kendini gösterirken iş yeri ve iş yeri çevresinde maddi kayıpların yaşanmasına da neden olmaktadır (Uçan, 2021; Çabuk, 2020; Wang, 2014). İş kazası sonucunda çalışanın yaşadığı depresyon durumu ve kaygı düzeyinin yüksek olması çalışanın çalışma gücünün kalıcı veya geçici bir süreliğine kaybetmesinden dolayı hem psikolojik hem de ekonomik olarak etkilenmesine neden olmaktadır. İşveren açısından kazalar verimliliği ve üretimi olumsuz yönde etkilemektedir. Makinanın zarar görmesi, ürünün geç teslim edilmesi neticesinde verilen cezalar, tedavi ve sağlı masrafları, yeni işçi için eğitim ve işi öğrenme süreci, geçici veya sürekli iş göremezlik ödenekleri, mahkeme masrafları vb. gibi işveren için önemli maliyetlere ve kurumsal hayatta kötü bir imaj yaratmasına neden olmaktadır (Çolak, 2010). Bir ülkede iş kazaları ve meslek hastalıklarının sayısının fazla olması ülkeler açısından itibar kaybına, diğer ülkelerle ekonomik rekabette geriye düşmeye ve hedeflenen refah seviyesine ulaşılamamasına neden olmaktadır. Dünya Sağlık Örgütü, iş kazalarından veya meslek hastalıklarından ölümlerin çok büyük boyutta toplumsal sağlık yükü oluşturduğunu, bu yükün maliyetinin ise dünyanın Gayri Safi Millî Hasılasının (GSMH) \%4-5'ini oluşturduğunu belirtmiştir (İSGGM, 2020; Kalkınma Planı, 2018). 
Türkiye'de aktif olarak eğitim ve öğretim faaliyetini sürdüren devlet üniversitesi sayısı 129 , vakıf üniversitesi sayısı 74 ve vakıf meslek yüksekokul sayısı 4 olup toplam 207 yükseköğretim kurumu bulunmaktadır. Yükseköğretim kurumlarında eğitim ve öğretim gören öğrenci sayıs1 7.740.502, öğretim elemanı sayıs1 166.225 ’tir. İstanbul özeline bakıldığında 57 adet yükseköğretim kurumu ve yükseköğretim kurumlarında görev alan top-lam 36.896 öğretim elemanı ve eğitim- öğrenim gören 1.109 .739 öğrenci bulunmaktadır (YÖK, 2020).

Yükseköğretim kurumları yüksek düzeyde bilimsel çalışma ve araştırmaların yapıldığı, bilgi ve teknolojinin üretildiği, bilim verilerinin yayınlandığı, gelişime ve kalkınmaya destek olan, ulusal ve uluslararası kurumlarla iş birliği yaparak bilim dünyası için çalışmalar yapan, evrensel ve çağdaş gelişmeye katkı sağlayan yapılardır. Yükseköğretim kurumlarının bir diğer amacı ise toplum yararına çalışmalar yapan ve yürüten, yurttaşlık sevgisi ile dolu, ülkesine karşı görev ve sorumluluklarını bilen ve bunları benimseyen, hür ve bilimsel düşünce gücüne, geniş bir vizyona sahip, ülke kalkınmasına ve ihtiyaçlarına cevap veren, aynı zamanda bir mesleğin bilgi, beceri, davranış ve genel kültürüne sahip vatandaşları yetiştirmektir (Kanun, 2547). Toplumda önemli ve saygın bir yere sahip olan yükseköğretim kurumları (devlet ve vakıf üniversitesi) fırsat ve imkân eşitliğini sağlayacak önlemler alarak nitelikli insan gücünün yetiştirirken özellikle bilim üretmekte ve üretilmesini özendirmekte, düşünmeye teşvik etmektedir. Bilimin, fikirlerin üretilmesi ve düşüncenin geliştirilmesi, geniş kitlelere yayılması, üniversite iç ve dış paydaşlarının eğitilmesi, yönlendirilmesi, bilgilendirilmesi yoluyla akademik, mesleki ve bireysel gelişimlerinin sağlanması yükseköğretim kurumlarının sahip olduğu altyapı (derslik, laboratuvar, kütüphane, kuluçka merkezi vb.) imkanları ile birlikte yükseköğretim kurumları tarafından gerçekleştirilen eğitim öğretim etkinlikleriyle mümkündür (Çabuk, 2020).

Yükseköğretim kurumları, üniversite ile yüksek teknoloji enstitüleri ve bunların bünyesinde yer alan fakülteler, enstitüler, yüksekokullar, konservatuvarlar, araştırma ve uygulama merkezleri ile bir üniversite veya yüksek teknoloji enstitüsüne bağlı meslek yüksekokullarını temsil etmektedir. Üniversite, bilimsel özerkliğe ve kamu tüzel kişiliğine sahiptir. Yüksek düzeyde eğitim-öğretim sağlar ve buna ek olarak bilimsel araştırma, yayın ve danışmanlık yapar. Fakülte, yüksek düzeyde eğitim- öğretim, bilimsel araştırma ve yayın yapan; kendisine birimler bağlanabilen yapıyı; Enstitü, üniversitelerde ve fakültelerde birden fazla benzer ve ilgili bilim dallarında lisansüstü, eğitim- öğretim, bilimsel araştırma ve uygulama yapan yapıyı; Yüksekokul, belirli bir mesleğe yönelik eğitim öğretime ağıllık veren yapıyı; Meslek Yüksekokulu, belirli mesleklere yönelik nitelikli insan gücü yetiştirmeyi amaçlayan, yılda iki veya üç dönem olmak üzere iki yıllık eğitim- öğretim sürdüren, ön lisans derecesi veren yapıyı ifade etmektedir (Kanun, 2547). Üniversite yerleşkesi içerisinde yer alan enstitü, fakülte ve meslek yüksekokulları ise içerisinde akademik ve mesleki gelişim ve pekiştirme için uygulamaların yapılmasına imkân sağlayan araştırma ve uygulama laboratuvarların, meslek atölyelerinin ve ayrıca öğretim elemanlarının kullanımında olan büroların da yer aldığı binalardan oluşmaktadır ve eğitim, öğretim ve bilimsel faaliyetler süresince de bu alanlar sürekli olarak kullanılmaktadır. Bununla birlikte araştırma ve uygulama laboratuvarların, meslek atölyelerinin ve bürolarda eğer gerekli önlemler alınmadığ takdirde iş kazalarına ve meslek hastalıklarına neden olabilecek çeşitli tehlikeler bulunmaktadır. Ne yazık ki bu alanlarda kullanılan alet, ekipman, makine, kimyasal ve biyolojik maddeler, elde edilen ürünler, binanın her türlü fiziki özellikleri ve ortam özellikleri için önleyici ve sınırlayıcı tedbirler alınmaz, uygulanmaz ve takip edilmez ise bu durum iç ve dış paydaşların iş kazası geçirmesine veya meslek hastalığına tutulmasına neden olabilmektedir.

İşyeri ekosistemi içerisinde var olan veya dışarıdan gelerek bu ekosistem içerisindeki tüm unsurların zarar ve hasar görmesine neden olabilecek tehlikelerin belirlenmesi, kayıp, yaralanma veya başka zararlı sonuçların meydana gelmesine neden olan ve tehlike kaynaklı risklerin tanımlanması ve belirlenmesi, tehlikelerin riske dönüşmesine yol açan faktörlerin analiz edilmesi, derecelendirilmesi, risklerin kontrol altına alınarak ya önlenmesi ya da sınırlandırılması çalışmalarıyla birlikte yapılan çalışmaların sürekli kontrolünün yapılması risk değerlendirilmesi ve yönetilmesi anlamına gelmektedir (Yönetmelik, 28515). Risk değerlendirmesi, hayatın ve özellikle çalışma hayatının bir gerçeği olmakla birlikte güvenli çalışma ve güvenli çalışma ortamlarının oluşturulması için şarttır (Uçan ve Karacığan, 2021). İs yerlerinde bir veya birden fazla metodun ayrı ayrı ya da birlikte kullanılmasıyla yapılan risk analizleri $\mathrm{o}$ iş yerinde risk değerlendirmesi için oluşturulan risk değerlendirme ekibi ile birlikte dolaylı olarak o işyerinde bulunan tüm çalışanların katılımıyla elde edilen veriler kullanılarak yapılmaktadır. Çalışanların iş yeri çalışan temsilcisiyle dolaylı olarak veya kendilerinden sözlü veya ramak kala olay formu ile yazılı olarak görüş alındığında doğrudan risk değerlendirme çalışmalarının bir parçası olmaktadır. Çalışanlara yaptıkları işle ilgili verilen sağlık ve güvenlik eğitimi ve işbaşı eğitimlerde iş yerinde yapılan iş ve işlemler, işyerinin ortam ve koşulları, çalışanın bizatihi yaptığı işten kaynaklı var olan tehlikeler ve tehlikelerden kaynaklı riskler, risklerin canlı ve cansız varlıklar üzerindeki etkileri anlatıl-maktadır (Yönetmelik, 30430). Bu sayede çalışanın tehlike ve risklerin farkına varmasıyla birlikte çalışanda risk algısı oluşturulmaktadır.

Risk iletişimi, risklerin analiz edilmesi sürecinde risk değerlendirme ekibi (Risk değerlendiricileri, risk yöneticileri vd. ilgili taraflar) tarafından çalışma ortamındaki risklerin algılanmasına ilişkin bilgi ve görüşler ile 
risk değerlendirmesi bulguları ve risk yönetimi kararlarının açıklamalarını da kapsayan bilgi ve düşüncelerin paylaşılması olarak tanımlanmaktadır. Risk iletişiminin sağlanmasıyla iş yeri ekosisteminde yer alan kişiler risk değerlendirmesi sonucunda alınan kararların gerekliliği anlayarak, kendisi ile birlikte o iş yerinde yer alan herkesin sağlığı, emniyeti ve güvenliği için alınması gereken önlem ve sınırlayıcı tedbirler, çalışanlar tarafından sergilenmesi gereken güvenli hareketler, karşılaştıkları riskler hakkında karar vermeleri sağlanmaktadır. İlgililer ve çalışanlar arasında tehlike ve tehlikelerden kaynaklı riskleri öğrenilmesi ve çalışanların bilinçli olarak tehlikeler ve tehlikelerden kaynaklı riskleri algılayabilmeleri için tüm tarafların açıklık, şeffaflık, bağımsız, yanıt verme kabiliyeti, zamanında iletişim, uygulama ilkelerine uygun olarak etkili bir risk iletişiminin kurulması gerekmektedir (Yönetmelik, 28152). Risk iletişiminin etkin olarak yürütülmesi ve tarafların risk değerlendirmesi çalışmaların aktif olarak katılması için çalışanların yazılı ve sözlü bildirim yapması, yapılan bildirimlerin zamanında değerlendirilerek gerekli çalışmaların yapılması, değerlendirme ve yapılan çalışmalar hakkında taraflara yazılı ve sözlü olarak bilgi verilmesi önem arz etmektedir.

\section{Materyal ve Yöntem}

Çalışma İstanbul ilinde faaliyet gösteren 57 yükseköğretim kurumunda (Devlet, Vakıf, Vakıfa Bağlı Meslek Yüksekokulu) görev alan öğretim elemanlarına yönelik olarak gerçekleştirilmiştir. Google form üzerinden oluşturulan sorular öğretim elemanlarına ait 19.294 farklı elektronik posta adresine gönderilmiştir. Katılımın artması için öğretim elemanlarına farklı zamanlarda olmak üzere üç (3) defa elektronik posta gönderilmiştir. Öğretim elemanlarından 573 tanesi çalışmaya katılım sağlamıştır. Katılımcılar tarafından verilen cevaplar tabloya aktarılarak verilen cevaplar değerlendirilmiştir.

\section{Araştırma Bulguları}

Çalışma kapsamında elde edilen bulgular yaş, medeni durum, eğitim durumu, çalışma durumu, görev aldığı birim, öğretim elemanlarının unvanları, mesleki deneyim süresi (mevcut yükseköğretim kurumu), temel iş sağlığı ve güvenliği eğitimi, iş kazası veya ramak kala olaya maruz kalma, maruz kalınan ya da tanık olunan ramak kala olay bildirim, ramak kala olay bildirimi sonunda tehlikelerin önlenmesi için yetkili birim tarafindan çalışma yapılması hakkında katılımcılardan elde edilen cevaplar başlıklar halinde verilmiştir.

Yaş

Çalışmaya katılan öğretim elemanlarının yaş dağılımları tabloda verilmiştir. Çalışmaya katılan öğretim elemanlarının yaş dağılımına bakıldığında 31- 40 yaş aralığındaki öğretim elemanı sayısının 188 (\%32,8), 20- 30 yaş aralığındaki öğretim elemanı sayısının $150(\% 26,2)$ ve $41-50$ yaş aralığındaki öğretim elemanı sayısının 135 $(\% 14,5)$ olduğu görülmektedir.

Tablo 3.1. Yaş Dağılımı

\begin{tabular}{|l|l|l|l|}
\hline \multirow{5}{*}{ Yaş } & Dağılım & Sayı (Adet) & Yüzde (\%) \\
\cline { 2 - 4 } & $20-30$ & 150 & 26,2 \\
\cline { 2 - 4 } & $31-40$ & 188 & 32,8 \\
\cline { 2 - 4 } & $41-50$ & 135 & 23,6 \\
\cline { 2 - 4 } & $51-65$ & 83 & 14,5 \\
\cline { 2 - 4 } & 65 ve üstü & 17 & 3,0 \\
\hline Toplam & $\mathbf{5 7 3}$ & $\mathbf{1 0 0}$ \\
\hline
\end{tabular}

\section{Medeni Durum}

Ankete katılan öğretim elemanlarının medeni durum dağılımları aşağıdaki tabloda gösterilmiştir. Çalışmaya katılan öğretim elemanlarından bekar olanların sayısı $228(\% 39,8)$ ve evli olanların sayısı 345'tir $(\% 60,2)$. 
Tablo 3.2. Medeni Durum Dağılımı

\begin{tabular}{|c|c|c|c|}
\hline \multirow{3}{*}{ Medeni Durum } & Durum & Sayı (Adet) & Yüzde (\%) \\
\hline & Bekar & 228 & 39,8 \\
\hline & Evli & 345 & 60,2 \\
\hline \multicolumn{2}{|c|}{ Toplam } & 573 & 100 \\
\hline
\end{tabular}

\section{Ĕ̆itim Durumu}

Ankete katılan öğretim elemanlarının eğitim durumu dağılımları aşağıdaki tabloda gösterilmiştir. Çalışmaya katılan öğretim elemanlarından lisans mezunu olanların sayısı $29(\% 5,1)$, yüksek lisans mezunu olanların sayısı $160(\% 27,9)$, doktora mezunu olanların sayısı 384'tür (\%67).

Tablo 3.3. Eğitim Durumu Dağılımı

\begin{tabular}{|c|c|c|c|}
\hline \multirow{4}{*}{ Eğitim Durumu } & Durum & Sayı (Adet) & Yüzde (\%) \\
\hline & Lisans & 29 & 5,1 \\
\hline & Yüksek Lisans & 160 & 27,9 \\
\hline & Doktora & 384 & 67,0 \\
\hline \multicolumn{2}{|c|}{ Toplam } & 573 & 100 \\
\hline
\end{tabular}

\section{Çalışma Durumu}

Ankete katılan öğretim elemanlarının 553'ü (\%96,5) tam zamanlı, 10’u (\%1,7) yarı zamanlı, 10’u (\%1,7) ders saat ücretli olarak yükseköğretim kurumlarında görev almaktadır.

\section{Tablo 3.4. Öğretim Elemanlarının Çalışma Durumu}

\begin{tabular}{|c|c|c|c|}
\hline \multirow{4}{*}{ Çalışma Durumu } & Durum & Sayı (Adet) & Yüzde (\%) \\
\hline & Tam Zamanlı & 553 & 96,5 \\
\hline & Yarı Zamanlı & 10 & 1,7 \\
\hline & Ders Saat Ücretli & 10 & 1,7 \\
\hline \multicolumn{2}{|c|}{ Toplam } & 573 & 100 \\
\hline
\end{tabular}

\section{Görev Alınan Birim}

Ankete katılan öğretim elemanlarının 28'i $(\% 4,9)$ rektörlük, 14’ü $(\% 2,4)$ enstitü, 419’u $(\% 73,1)$ fakülte, 35'i $(\% 6,1)$ yüksekokul, 205'i $(\% 13,4)$ meslek yüksekokulu bünyesinde görev almaktadır.

Tablo 3.5. Öğretim Elemanlarının Görev Aldıkları Birim

\begin{tabular}{|c|l|c|c|}
\hline \multirow{4}{*}{ Görev Aldığı Birim } & \multicolumn{1}{|c|}{ Durum } & Sayı (Adet) & Yüzde (\%) \\
\cline { 2 - 4 } & Rektörlük & 28 & 4,9 \\
\cline { 2 - 4 } & Enstitü & 14 & 2,4 \\
\cline { 2 - 4 } & Fakülte & 419 & 73,1 \\
\cline { 2 - 4 } & Yüksekokul & 25 & 6,1 \\
\cline { 2 - 4 } & Meslek Yüksekokulu & $\mathbf{5 7 3}$ & 13,4 \\
\hline
\end{tabular}

\section{Öğretim Elemanlarının Unvanı}

Ankete katılan öğretim elemanlarının 61'i (\%10,6) Profesör Dr./ Profesör, 67'si $(\% 11,7)$ Doçent Dr./ Doçent, 149’u (\%26) Doktor/ Dr. Öğretim Üyesi, 139’u (\%24,3) Öğretim Görevlisi, 157’si (\%27,4) Araştırma Görevlisi unvanına sahiptir.

\section{Tablo 3.6. Öğretim Elemanlarının Unvanları}

\begin{tabular}{|c|c|c|c|}
\hline \multirow{6}{*}{$\begin{array}{l}\text { Öğretim Elemanlarının } \\
\text { Unvanları }\end{array}$} & Unvan & \multirow{2}{*}{$\frac{\text { Sayı (Adet) }}{61}$} & \multirow{2}{*}{$\begin{array}{c}\text { Yüzde (\%) } \\
10,6\end{array}$} \\
\hline & Prof. Dr./ Prof. & & \\
\hline & Doç. Dr./ Doç. & 67 & 11,7 \\
\hline & Dr./ Dr. Öğretim Üyesi & 149 & 26,0 \\
\hline & Öğretim Görevlisi & 139 & 24,3 \\
\hline & Araştırma Görevlisi & 157 & 27,4 \\
\hline \multicolumn{2}{|c|}{ Toplam } & 573 & 100 \\
\hline
\end{tabular}




\section{Mesleki Deneyim Süresi (Mevcut Yükseköğretim Kurumu)}

Ankete katılan öğretim elemanlarının 47'si (\%8,2) 0- 6 ay, 54'ü $(\% 9,4) 7$ Ay- 1 yıl, 225'i (\%39,3) 2 yıl- 5 yıl, 116 ’s1 (\%20,2) 6 yıl- 10 yıl), 131’i (\%22,9) 11 yıl ve üstünde mesleki deneyim süresine sahiptir.

Tablo 3.7. Mesleki Deneyim Süresi (Mevcut Yükseköğretim Kurumu)

\begin{tabular}{|c|c|c|c|}
\hline \multirow{6}{*}{ Deneyim Süresi } & Süre & \multirow{2}{*}{$\begin{array}{c}\text { Sayı (Adet) } \\
47\end{array}$} & \multirow{2}{*}{$\begin{array}{c}\text { Yüzde (\%) } \\
8,2 \\
\end{array}$} \\
\hline & $0-6 \mathrm{Ay}$ & & \\
\hline & 7 Ay- 1 Y1l & 54 & 9,4 \\
\hline & $2 Y_{11}-5 Y_{11}$ & 225 & 39,3 \\
\hline & 6 y1l- 10 Y1l & 116 & 20,2 \\
\hline & 11 Y1l ve üstü & 131 & 22,9 \\
\hline \multicolumn{2}{|c|}{ Toplam } & 573 & 100 \\
\hline
\end{tabular}

\section{Temel İş Sağlığı ve Güvenliği Eğitimi}

Ankete katılan öğretim elemanlarının 370'si $(\% 64,6)$ görev aldığı üniversitede temel iş sağlığı ve güvenliği eğitimi almıştır. Öğretim elemanlarının 203'üne $(\% 35,4)$ ise görev aldığ1 üniversitede temel iş sağlığı ve güvenliği eğitimi verilmemiştir.

Tablo 3.8. Temel İş Sağlığı ve Güvenliği Eğitimi

\begin{tabular}{|c|l|c|c|}
\hline \multirow{3}{*}{ Temel İş Sağlığı ve Güvenliği Eğitimi } & Durum & Sayı (Adet) & Yüzde (\%) \\
\cline { 2 - 4 } & Evet & 370 & 64,6 \\
\cline { 2 - 4 } & Hayır & 203 & 35,4 \\
\hline Toplam & & $\mathbf{5 7 3}$ & $\mathbf{1 0 0}$ \\
\hline
\end{tabular}

\section{İş Kazası ve Ramak Kala Olaya Maruz Kalma Durumu}

Ankete katılan öğretim elemanlarından 69’u $(\% 11,6)$ görev aldığ 1 üniversitede iş kazası geçirmiş veya ramak kala olay yaşamıştır. 448'si $(\% 88,4)$ görev aldığı üniversitede iş kazası geçirmemiş veya ramak kala olay yaşamamıştır.

Tablo 3.9. İş Kazası veya Ramak Kala Olaya Maruz Kalma

\begin{tabular}{|c|c|c|c|}
\hline \multirow{2}{*}{ İş Kazası veya Ramak Kala Olaya Maruz Kalma } & Durum & Sayı (Adet) & Yüzde (\%) \\
\cline { 2 - 4 } & Evet & 69 & 11,6 \\
\cline { 2 - 4 } & Hayır & 448 & 88,4 \\
\hline Toplam & $\mathbf{5 7 3}$ & $\mathbf{1 0 0}$ \\
\hline
\end{tabular}

Maruz Kalınan ya da Tanık Olunan Ramak Kala Olay Bildirim

Ankete katılan öğretim elemanlarından 23'ü $(\% 33,3)$ maruz kaldığ 1 ya da tanık olduğu ramak kala olayı yükseköğretim kurumunda görevli birime veya yetkiliye yazılı veya sözlü olarak bildirmiştir. 46's1 (\%66,7) maruz kaldığı ya da tanık olduğu ramak kala olayı yükseköğretim kurumunda görevli birime veya yetkiliye yazılı veya sözlü olarak bildirmemiştir.

Tablo 3.10. Maruz Kalınan ya da Tanık Olunan Ramak Kala Olay Bildirim

\begin{tabular}{|c|c|c|c|}
\hline \multirow{3}{*}{$\begin{array}{c}\text { Maruz Kalınan ya da Tanık Olunan Ramak Kala Olay } \\
\text { Bildirim }\end{array}$} & Durum & Sayı (Adet) & Yüzde (\%) \\
\hline & Evet & 23 & 33,3 \\
\hline & Hayır & 46 & 66,7 \\
\hline Toplam & & 573 & 69 \\
\hline
\end{tabular}

Ramak Kala Olay Bildirimi Sonunda Tehlikelerin Önlenmesi İçin Yetkili Birim Tarafından Çalışma Yapılması

Öğretim elemanı tarafından yapılan ramak kala olay bildirimlerden 23'ü $(\% 33,3)$ için tehlikelerin önlenmesi veya ortadan kaldırılmasına yönelik olarak yetkili birim tarafından çalışma yapılmışken yapılan bildirimlerden 46'sı $(\% 66,7)$ için tehlikelerin önlenmesi veya ortadan kaldırılmasına yönelik olarak yetkili birim tarafından çalışma yapılmamıştır. 
Tablo 3.11. Ramak Kala Olay Bildirimi Sonunda Tehlikelerin Önlenmesi İçin Yetkili Birim Tarafından Çalışma Yapılması

\begin{tabular}{|c|l|c|c|}
\hline \multirow{2}{*}{$\begin{array}{c}\text { Ramak Kala Olay Bildirimi Sonunda Tehlikelerin Önlenmesi } \\
\text { İçin Yetkili Birim Tarafından Çalışma Yapılması }\end{array}$} & Durum & Sayı (Adet) & Yüzde (\%) \\
\cline { 2 - 4 } & Evet & 23 & 33,3 \\
\cline { 2 - 4 } Toplam & Hayır & 46 & 66,7 \\
\hline Ty & $\mathbf{5 7 3}$ & $\mathbf{6 9}$ \\
\hline
\end{tabular}

\section{Tartışma ve Sonuç}

Yükseköğretim kurumları yerleşkelerin büyüklüğüne ve yerleşimlerine göre içerisinde dersliklerin, çalışma odaları, laboratuvar, atölyelerin bulunduğu eğitim amaçlı binaların yanı sıra kültür, sanat ve spor faaliyetlerinin gerçekleştirildiği alanlar ve spor merkezleri, idari işlerin yürütüldüğü binalar, teknokentler, araştırma merkezleri, kütüphane, market, kuaför- berber, lokanta, yemekhane, yurt gibi yapıları bulundurmaktadır. Ayrıca üniversite yerleşkelerinin büyüklüğüne göre içerisinde araç yolları bulunmaktadır. Yükseköğretim kurumları eğitimöğretimin gerçekleştirildiği yer olmakla beraber öğretim elemanları, idari personel için çalışma alanlarıdır ve iş sağlığı ve güvenliğine ilişkin iş yeri tehlike sınıfı tebliğine göre az tehlikeli sınıfta yer almaktadır. Az tehlikeli sınıfta yer almasına rağmen özellikle teknik meslek yüksekokulları, fen ve edebiyat fakültelerine ve mühendislik fakültelerine ait atölyeler ve laboratuvarlar, sağlık meslek yüksekokullarına, sağlık fakülteleri, eczacılık ve tıp fakültelerine ait laboratuvar, poliklinikler bulunmaktadır. Laboratuvar ve atölyelerde yapılan işler, kullanılan maddeler, alet ve ekipmanlardan kaynaklı olarak öğretim elemanları ve diğer çalışanlarla birlikte öğrencilerin sağlığı ve güvenliğini olumsuz etkileyecek fiziksel, kimyasal, biyolojik vd. risk etmenlerini içermektedir. Eğitim, bilimsel araştırma ve geliştirme, diğer mesleki, bilimsel ve teknik faaliyetlerin yapıldığı işyerlerinde 8.311 kişi iş kazası geçirmiş ve 1 çalışan meslek hastalığına tutulmuştur. İş kazası sonucu 6 çalışan yaşamını kaybetmiştir (SGK, 2019).

İş kazası sayılarına bakıldığında yükseköğretim kurumlarında bulunan öğrenci, idari personel, öğretim elemanı ve ziyaretçilerin sağlık ve güvenliği için iş sağlığı ve güvenliği hizmetlerinin yerine getirilmesi gerekmektedir. Yükseköğretim kurumlarında iş sağlı̆̆ ve güvenliği hizmetlerinin uygulanması, takibi ve kontrolünde tüm çalışanların (Öğretim elemanı, idari personel) sorumlulukları bulunmaktadır.

Uygulamalı eğitimlerin yapıldığı okullarda atölye uygulamalarının yoğun olmasından iş güvenliği malzeme ve teçhizat eğitimlerinin verildikten sonra kullanılmasına izin verilmesi (Çetinkaya, 2019), laboratuvar çalışanlarının tehlikeler konusunda bilinçlenmesi ve farkındalıklarının artması amacıyla laboratuvar güvenliği ile ilgili eğitimlerin verilmesi, laboratuvar güvenlik politikasının belirlenmesi, laboratuvar güvenliği için sorumlunun yetkilendirilmesi, güvenlik bilgi formlarının tedarik edilmesi, atık yönetimi prosedürünün oluşturulması, acil çıkışların işaretlenmesi (Ersoy, 2019), personellere yönelik karşılaşabilecekleri tehlikeler hususunda eğitim verilmesi ve bu eğitimlerin belirli periyodlarda tekrarlanması (Menevşe, 2016), üniversite birimlerinde çalışanlarının eğitimlere yönelik bilinç düzeylerinin artırılması (Yenisarı, 2019) gerekmektedir.

Çalışanların sağlık, emniyet ve güvenliğinin sağlanması ve devamlılığı yükseköğretim kurumu yönetimi sorumluluğundadır. Rektörlüğe veya müdürlüğe bağlı iş sağlı̆̆1 ve güvenliği koordinatörlüğü yoluyla ya da ortak sağlık ve güvenlik biriminden hizmet alarak iş sağlığı ve güvenliği hizmetini yerine getirilmektedir. İş sağlığı ve güvenliği hizmetleri arasında risk değerlendirmesi ve acil durum planı hazırlama çalışmaları, iş sağlığı ve güvenliği eğitimi, periyodik ölçümler, iş sağlığı ve güvenliği çalışmalarının takibi ve kontrolü, sağlık muayeneleri ve periyodik sağlık kontrolleri bulunmaktadır.

Katılımcıların verdiği cevaplar dikkate alındığında öğretim elemanlarının tamamına iş sağlığı ve güvenliği eğitimlerinin verilmediği görülmektedir. Temel seviyede iş sağlığı ve güvenliği eğitimi ve işe başlama eğitimi çalı-şan fiilen çalışmaya başlamadan önce veya az tehlikeli sınıfta fiilen çalışmaya başladıktan hemen sonra verilmelidir. İş sağlığı ve güvenliği eğitimi ilgili yönetmeliğe göre gerekli haller dışında 3 (üç) yılda bir yenilenmelidir (Yönetmelik, 28648).

İş yerlerinde iş kazası, meslek hastalığ 1 ve ramak kala olayların gerçekleşmesinin önlenmesi çalışanların fiziksel, ruhsal ve sosyal yönden iyilik hallerinin devamına katkı sağlamaktadır. Katılımcıların verdiği cevaplar dikkate alındığında yükseköğretim kurumlarında iş kazası ve ramak kala olaylar meydana gelmektedir. İş kazası, meslek hastalığı ve ramak kala olayların önlenmesi için yükseköğretim kurumlarında çalışanlar başta olmak üzere öğrencilerin sağlığının ve güvenliğinin sağlanması için çalışmaların yapılması ve çalışmaların sürekli kontrol edilmesi gerekmektedir.

Risk değerlendirmesi çalışmaları ile işyerlerinde var olan veya dışarıdan gelebilecek tehlike ve bu tehlikelerden kaynaklı riskler önleyici veya sınırlandırıcı tedbirler alınarak kabul edilebilir seviyeye indirilebilir veya tamamen 
ortadan kaldırılabilir. Bu sayede iş kazası, meslek hastalığı ve ramak kala olaylar önlenebilir veya etkileri sınırlandırılabilir. Ayrıca risk değerlendirmesi çalışmaları ile kaza sonrasında yapılacak çalışmaları ve süreçleri planlayarak kazanın ve hastalı̆̆ın çalışanlar ve işyeri üzerindeki olumsuz etkilerinin azaltılmasını sağlamaktadır. Buna örnek olarak meydana gelen iş kazası sonucu uzuv kopması yaşandıktan sonra uygulanacak ilk yardım belirlenmesi, kazazedenin sevk edileceği hastanenin seçilmesi, müdahale ve ameliyatı yapacak doktor ve cerrahın belirlenmesi, hastaneden çıtıktan sonra uygulanacak rehabilitasyon çalışmalarının ve gidilecek rehabilitasyon merkezinin seçilmesi çalışanın daha az zararla durumu atlatmasına imkân sağlanabilecektir. Risk değerlendirmesi çalışmalarında tehlikeler ve tehlikelerden kaynaklı risklerin belirlenmesinde işyerinde yapi-lan teknik kontroller, makine ve maddelerin kullanım kılavuzları ile güvenlik bilgi formları vd. bilgilerin yanı sıra iş yeri geçmişinde meydana gelen iş kazalarının, meslek hastalıklarının ve ramak kala olaylarının kayıtları kullanılmaktadır. İş kazaları raporları işyeri yetkilileri tarafından tutulmaktadır ve arşivlenmektedir. Ramak kala olaylar ise çalışanların bildirmesi yoluyla raporlanmakta ve arşivlenmektedir. Ramak kala olayların çalı-şanlar tarafindan ilgili yetkililere ve birimlere iletilmesi için çalışanların yazıll, sözlü ve elektronik olarak bildirmesine imkân sağlayacak araçlar kullanılmalı ve çalışanlar teşvik edilmelidir. Katılımcıların verdikleri cevaplara bakıldığında ramak kala maruz kalanların tamamının bildirim yapmadığı, yapılan bildirimlerin ise tamamının dikkate alınarak ramak kala olaya neden olan tehlikelerin ortadan kaldırılmadığı görülmektedir.

Tehlike sınıfı fark etmeksizin tüm iş yerlerinde iş yeri ekosistemini oluşturan canlı ve cansız varlıkların sağlık, emniyet ve güvenliğinin sağlanması için iş sağllğı ve güvenliği hizmetlerinin uygulanması ve çalışanların çalışmalara direkt veya doğrudan katkı sunması sağlanmalıdır. İş yerlerinde geliştirilecek risk iletişimi ve beraberin-de çalışanlarda oluşturulacak risk algısı sayesinde çalışanların kendileri, diğer insanlar ve cansız varlıklar için tehdit oluşturacak tehlikeler ve tehlikelerden kaynaklı riskleri algılamaları ve bunları bildirmeleri sağlanabilecek-tir. Risk algısı gelişen çalışanların tehlike ve riskleri ilgili birim ve yetkililere bildirmesi, bildirilen tehlikelerin yetkililer tarafindan yapılacak risk kontrol tedbirleri sayesinde hızlı ve etkin şekilde kaldırılmasıyla yükseköğretim kurumları da dahil tüm işyerlerindeki herkes ve her şey için sağlıklı, emniyetli ve güvenli olması sağlanacaktır.

\section{Kaynaklar}

Altınöz, Ü. (2017). Yoğun Bakımda Çalışan Hemşirelerde Çalışma Ortamı Algısı, Psikolojik Distres ve Etkileyen Faktörler. Psikiyatri Hemşireliği Dergisi- Journal of Psychiatric Nursing 2017;8(2):95-101

Aydıner Boylu, A., Paçacıoğlu, B., (2016). Yaşam Kalitesi ve Göstergeleri. Akademik Araştırmalar ve Çalışmalar Dergisi (AKAD), 8 (15), 137-150.

Çabuk, A., (2020). İstanbul Anadolu Yakasında Eğitim- Öğretim Faaliyetini Gerçekleştiren Vakıf Üniversitelerinde Görev Alan Öğretim Elemanlarının İş Sağlığı ve Güvenliğgi Algısının Anket Yöntemiyle Ölçülmesi, Yayınlanmış Yüksek Lisans Tezi, İş Sağlığı ve Güvenliği Fen Bilimleri Enstitüsü, Kocaeli Üniversitesi, Kocaeli.

Çabuk, A., (2020). Kasım 2002 ve Sonrası Türkiye Büyük Millet Meclisinde Grubu Bulunan Siyasi Partilerin Beyannamelerinde İş Sağlığı ve Güvenliği. Ohs Academy, 3 (3), 183-193. DOI: 10.38213/ohsacademy.771232

Çetinkaya, A, Ulusoy, İ. (2019). Mesleki ve Teknik Liselerde Atölye Uygulamalarında İş Sağlı̆̆ı ve Güvenliği. Ohs Academy, 2 (3), 135-142

Çetinkaya, F, Baykent, G. (2017). İşyeri Çalışma Ortamı Koşullarının Ergonomik Yönden İncelenmesi (Örnek: Şekerleme Firması). Uşak Üniversitesi Fen ve Doğa Bilimleri Dergisi, 1 (1), 15-31.

Çolak, F., (2010). İş Kazası Geçiren ve Geçirmeyen İş Görenlerin Depresyon, Öfke, Kaygı, Algı, Dikkat ve Dişa-dönük-İçedönüklükleri Açısından Karşılaştırılması. Maltepe Üniversitesi Sosyal Bilimler Enstitüsü Psikoloji Anabilim Dalı Endüstri ve Örgüt Psikolojisi Programı Yüksek Lisans Tezi

Ersoy, S, Çelenk Kaya, E. (2019). Bir Kamu Üniversitesi Gıda Mühendisliği Laboratuvarları Risk Analiz Uygulaması. Gümüşhane Üniversitesi Sağlık Bilimleri Dergisi, 8 (4), 411-423.

Menevşe, E., (2016). Biyokimya Laboratuvarı Çalışanlarının İş Güvenliği Profilleri ve Kişisel Koruyucu Dedbirlerin Uygulanmasındaki Mesleki Tutumlarının Değerlendirilmesi. Genel Tıp Dergisi, 2016;26 (Ek 1):39-47

Uçan, R., Karacığan, A. O., (2021), İş Birlikçi Endüstriyel Robotlarda İş Güvenliği Yaklaşımı, Efe Akademi Yayinevi

Uçan, R., Uçan, A., (2021), Örneklerle İş Kazalarının İşverene Maliyeti, Efe Akademi Yayınevi 
Ulukaya, F, Çögenli, M. (2020). Gürültülü Çalışma Ortamının Çalışanlar Üzerindeki Psikososyal Etkilerinin İncelenmesi: Tekstil Sektöründe Ampirik Bir Çalışma. Anadolu Akademi Sosyal Bilimler Dergisi, 2 (1), 131140.

Ünsar, A., (2004). İş Kazaları ve Örgütsel Verimlilik. Verimlilik Dergisi, 2004 (3)

Yenisarı, B., Mestav, B, Öztürk, Ö. (2019). Üniversite Çalışanlarının İş Sağlığı ve Güvenliği Eğitimi Konusundaki Bilinç Düzeylerinin Araştırılması. Çanakkale On sekiz Mart Üniversitesi Fen Bilimleri Enstitüsü Dergisi, 5 (2), 339-355.

Yönetmelik, Risk Değerlendirme Komite ve Komisyonlarının Çalışma Usul ve Esasları Hakkında Yönetmelik, Resmî Gazete Tarihi 24.12.2011 Sayısı 28152

Yönetmelik, İş Sağlığı ve Güvenliği Risk Değerlendirmesi Yönetmeliği, Resmî Gazete Tarihi 29.12.2012 Sayısı 28512

Yönetmelik, Çalışanların İş Sağlığı ve Güvenliği Eğitimlerinin Usul ve Esasları Hakkında Yönetmelik, Resmî Gazete Tarihi 15.05.2013 Sayıs1 28648

Yönetmelik, Çalışanların İş Sağlığı ve Güvenliği Eğitimlerinin Usul ve Esasları Hakkında Yönetmelikte Değişik-lik Yapılmasına Dair Yönetmelik, Resmî Gazete Tarihi 24.05.2018 Sayısı 30430

Wadsworth, E., \& Walters, D., (2019). Safety And Health At The Heart Of The Future Of Work: Building On 100 Years Of Experience. Geneva: International Labour Office. Https://Www.İlo.Org/Safework/Events/Safeday/Wcms_687610/Lang--En/İndex.Htm

Wang, B., Wu, L. K., Huang, W. P., (2018). What Are The Challenges, Goals, And Tasks Of Occupational Health İn China's Thirteenth Five-Year Plan (13th Fyp) Period. Journal Of Occupational Health, 60 (3), 208-228 İnternet Sitesi: Risk İletişimi, Tarım ve Orman Bakanlığı, Url Adresi: Https://Www.tarimorman.gov.tr/konu/954/risk-iletisimi Erişim Tarihi: 11 Şubat 2021

\section{Conflict of Interest / Çıkar Çatışması}

Yazarlar tarafından herhangi bir çıkar çatışması beyan edilmemiştir.

No conflict of interest was declared by the authors. 